\title{
Medieval and early modern ceramics in urban and rural Norway as evidence for trade within the Hanseatic world
}

\author{
VOLKER DEMUTH
}

Demuth, V. 2019. Medieval and early modern ceramics in urban and rural Norway as evidence for trade within the Hanseatic world. AmS-Skrifter 27, 121-132, Stavanger, ISSN 0800-0816, ISBN 978-82-7760-183-0.

\begin{abstract}
In Norway, pottery from the fourteenth to seventeenth centuries is always imported and mostly concentrated in the urban centres. The few finds of pottery from this period in a non-urban context can, however, shed light on the spreading of a continental or Hanseatic culture into the periphery of this country. This paper provides a broad overview of archaeological finds of pottery from Bergen and their implications as sources of cultural history. Furthermore, this paper presents various rural and underwater finds of late medieval and early modern pottery in different regions of Norway, along with a discussion of a possible interpretation of the finds as sources for Hanseatic history.
\end{abstract}

Volker Demuth, Museum of Archaeology, University of Stavanger, N-4036 STAVANGER, NORWAY.

E-mail: volker.demuth@uis.no

Keywords: pottery, stoneware, Norway, fish-trade, Hanse, urban vs rural, consumption habits

As in most other European countries, medieval archaeology in Norway has been predominantly urban archaeology; as in most other European towns, in Norway, pottery forms the majority of archaeological finds from the cultural layers in medieval towns. However, unlike any other European country - aside from the strongly associated North Atlantic island of Iceland - Norway had no native pottery: all medieval and early modern ceramic in Norway is imported. There are no traces of any pottery production before immigrant potters from Denmark and northern Germany started earthenware production in the late seventeenth century. ${ }^{2}$

The following paper tries to provide an overview of a selection of finds of medieval and early modern pottery in Norway. The finds were selected and examined based on their evidence of contact between the places where they were found and the continental areas of the Hanseatic world. To start, I shall summarize the pottery found in Bergen. This was the largest town in Norway throughout the medieval and early modern period and, with the Hanseatic Kontor at Bryggen, it housed one of the Hanse's most important dependencies outside the Hanseatic heartland. The pottery found in Bergen exemplifies the contact between Norway, Britain and mainland Europe. It also shows the variety of pottery that was traded across the North Sea. An overview of the pottery sequence in Bergen should give a suitable background to evaluate the pottery found outside the urban centres, which I shall present later.

For an archaeologist, especially when trained in a field context, the research of pottery generally comes quite naturally, as it is very often the predominant find material and it is quite often also the best material for dating archaeological layers and structures. Historians, on the other hand, may often question the contribution of all this research on heaps of fragmented sherds - other than producing some nice illustrations of material culture. There are, however, various aspects of life in the medieval and early modern period, where the contemporary pottery may give a unique perspective on the historical reality. In addition to other sources, such as written documents and contemporary art, the archaeological remains directly reflect commercial and domestic activities. Due to their frequent appearance and definable origin, finds of pottery are particularly suitable as a basis for dis- 
cussions on issues like long-range trading and cultural influence. The pottery itself was mostly a commodity of trade, thus exemplifying trade routes. Furthermore, the use of specific vessels reflects certain cultural habits, which were transmitted or passed on by mutual contacts. Last but not least, highly decorated pottery may itself have acted as an agent for specific meanings and mentalities, with the decoration as the medium. ${ }^{3}$

After presenting pottery from Bergen and considering its significance as a source for discussing Hanseatic history, I shall present some finds from rural Norway and discuss the question of a potential Hanseatic influence in Norway outside the urban centres.

\section{The Bergen pottery sequence in the late medieval and early modern period}

This section provides a broad overview of the late medieval and early modern pottery found in Bergen. I shall present certain types of pottery in more detail, as these also occur in a rural context and are relevant to that discussion later in this paper.

As mentioned above, pottery forms a very large portion of all archaeological finds from Bergen. Over 100,000 pottery fragments have been discovered at the main excavation site at Bryggen, the former German wharf. ${ }^{4}$ In 1982, British researchers Ian Reed and Rory Dunlop initially sorted this enormous amount of material by origin. Various researchers have subsequently published their examinations of certain groups of the pottery from Bryggen and other sites in Bergen. ${ }^{5}$

The pottery found in Bergen was imported from different regions during the medieval and early modern period, with considerable variations in the main sources over time. In the oldest layers, from the twelfth and early thirteenth centuries, hard-fired earthenware, mainly of western German origin and glazed Flemish Ardenne-ware are predominant, aside from some English pottery. ${ }^{6}$ The majority of thirteenthand fourteenth-century pottery in Bergen constitutes various types of English earthenware, mostly glazed, alongside a variety of southern Scandinavian and northern German pottery. During the fourteenth century, various types of German stoneware become more and more dominant in the Bergen ceramic sequence, culminating in the fifteenth century. From the sixteenth century on, in addition to the stoneware - which is still quite frequent - there is an increasing amount of glazed earthenware, mainly from the Netherlands and northern Germany.

The variations in the areas of origin are reflected both in the form and in the usage of the pottery. During the twelfth century, cooking and storage vessels are just as common as drinking and pouring vessels. In the fourteenth and fifteenth centuries, pottery is predominantly used as tableware for drinking and pouring; cooking pots seem to occur rather rarely. In the sixteenth and seventeenth centuries, new forms of pottery appear on the Bergen market simultaneously with other areas of northern Europe. Alongside various cooking pots of different shapes, previously uncommon tableware such as plates and bowls - often highly decorated - become frequent in the archaeological material. However, drinking and pouring vessels of German stoneware make up a large proportion of the pottery found in Bergen.

How can these archaeological finds of pottery be interpreted to function as a source for describing the contact between the Hanseatic world and Norway, i.e. Bergen? Of course, imported pottery is a direct indication of trade connections and it shows how different regions in the Hanseatic world were interacting. Although pottery may not necessarily indicate direct trade between production and consumption areas, the analysis of ceramics may hint at how trading routes were organised. ${ }^{7}$ As a commodity of everyday use, pottery also provides insight into material aspects of everyday life. This is especially true where ceramic objects were used for preparing, storing or consuming food and beverages. Hence, basic cultural elements, such as consumption habits and table culture, are directly mirrored in the pottery. Specific types of ceramics may serve as 'markers' for certain cultural phenomena and their spread into different regions. When it comes to immaterial aspects of life, such as mentality, worldview and ideology, these may be reflected directly in the motifs that decorated the pottery. Particularly, highly decorated pottery may have functioned as a medium for certain meanings which can be related directly to other contemporary sources, such as documents and art. ${ }^{8}$

\section{Trade routes and connections}

Though the pottery in Bergen or other trading towns is clear evidence of long-range contact, it is important to bear in mind that ceramics were transported from the production areas to various trading centres and redistributed from these, often with several steps in 
between. Thus, the appearance of certain ceramic wares does not necessarily represent direct trade connections. The ways in which the pottery found in Norway was distributed must be discussed in more detail to produce convincing models of interpretation.

As mentioned above, the majority of ceramic finds in Bergen from the late fourteenth and especially in the fifteenth century are German stoneware. Among the different stoneware production centres, the stoneware produced in the small town of Siegburg outnumbers any other production area by far. To analyse the appearance of this pottery in Bergen during the fourteenth and fifteenth centuries, a closer examination of the finds from fire layers is appropriate, as the fire layers are the closest thing we have to single context finds among the Bergen material. Bergen was regularly devastated by fires, which are frequently mentioned in various written sources. Accordingly, fire layers are frequently found in the archaeological stratigraphy in Bergen. The controversial question of the extent to which archaeological fire layers can be related to historically documented fires has been debated by various scholars. ${ }^{9}$ It is beyond the scope of this paper to discuss these methodological issues. For this paper, I have followed the identification of archaeological fire layers with historically documented fires made by the primary excavator of Bryggen, Asbjørn Herteig. ${ }^{10}$ In the layers from the fires of 1393 and 1413, about 65 per cent of all pottery is German stoneware. Siegburg represents 36 per cent of all pottery in the fire layer from 1393, increasing to 56 per cent in the fire layer from 1413. In a fire layer that most probably represents a fire in 1476, 78 per cent of all pottery is German stoneware - with Siegburg products alone making up to 67 per cent of all pottery. ${ }^{11}$ These numbers show the increasing amount of German stoneware in general and Siegburg stoneware in particular among the Bergen pottery in the late Middle Ages.

To what extent does this archaeological fact increase our insight into the late medieval trade connections to and from Bergen? Though there were well-established trade routes to the Rhine area, the great amount of pottery from the Rhineland must not be taken as evidence for the amount of direct trade between Bergen and the towns along the Rhine or at its mouth. The dominance of Siegburg stoneware may rather be explained by the dominance of the Siegburg pottery industry throughout the Hanseatic network. In a way, Siegburg stoneware is a 'type fossil' for Hanseatic trading activity. This ceramic was extensively traded between the different ports along the North Sea and

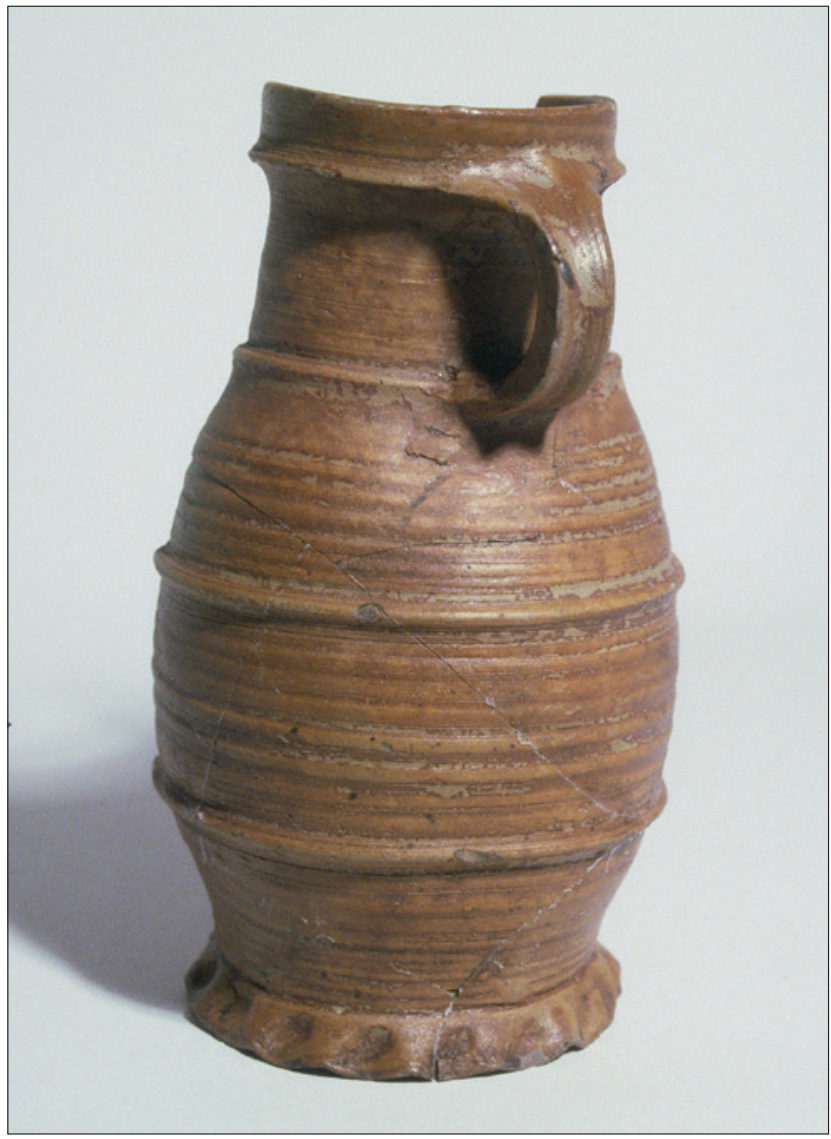

Fig. 1. Small stoneware jug, early fourteenth century, produced presumably in Bengerode, Lower Saxony, and found in layers from the end of the fourteenth century in Bergen (photo: Volker Demuth).

Baltic shores, so Siegburg stoneware found in Norway may very well have been brought there from a town in the Baltic where Siegburg stoneware was very frequent in the fourteenth and fifteenth centuries. ${ }^{12}$

Certain other pottery wares may nevertheless indicate direct trading contact, as their dispersion seems to be restricted to specific find spots and trading towns. In particular, I would interpret stoneware from the Upper Weser region in Lower Saxony as marker of the trade connections between Bremen and Norway in the fourteenthand fifteenth century. This characteristic stoneware makes up about 3-7 per cent of all pottery found in the fire layers from 1393 to 1476 in Bergen (Fig. 1). In the same period, the dominant Siegburg products largely replaced the Lower Saxon stoneware in many Hanseatic towns, where it had frequently been used in the late thirteenth and fourteenth centuries. This appears particularly in Baltic towns such as Rostock, Greifswald or Stralsund, ${ }^{13}$ but also in inland towns near the production area, such as Höxter. ${ }^{14}$ Yet, in several towns, the characteristic Lower Saxon stoneware from production sites such as Bengerode 


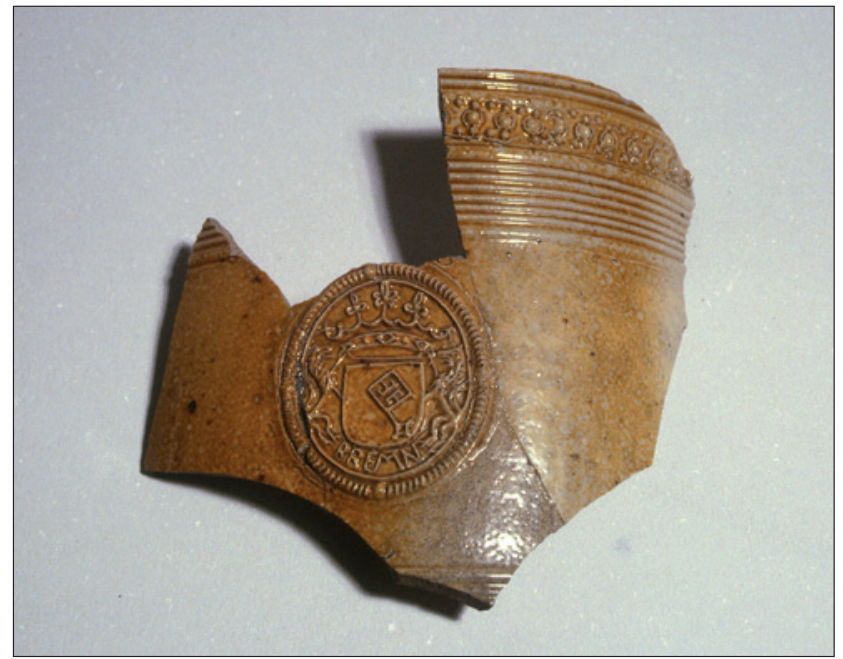

Fig. 2. Detail of a Raeren stoneware tankard, found in Bergen, showing the coat of arms of Bremen (photo: Volker Demuth).

or Coppengrave ${ }^{15}$ still seems to be in use in the later fourteenth and fifteenth centuries. In particular, this seems to be the case in Bremen, where Lower Saxon stoneware is found in closed contexts dating to the middle of the fifteenth century. ${ }^{16}$ It seems quite natural that this pottery is found in significant numbers in Bremen, as Bremen is at the mouth of the Weser river and was an intersection point between river and sea trade and a staple market for all goods traded up or down the river. Also in the small Hanseatic inland town of Einbeck, not far from the production sites and famous for its beer production, Lower Saxon stoneware still appears frequently in find contexts from the early fifteenth century. ${ }^{17}$ A large proportion of the Lower Saxon stoneware in Bergen was found in layers dating to a period when this pottery is no longer found in larger amounts in any other major Hanseatic harbour town than Bremen. Thus, I would interpret the Lower Saxon stoneware in Bergen as a clear marker of trading ties with Bremen (Fig. 2). The archaeological material may directly reflect the contact between Bremen and Bergen, which are also proven by written sources..$^{18}$ In the sixteenth century, many ships sailed directly from Bremen to Bergen. ${ }^{19}$ This traffic seems to have been quite steady, starting as early as the thirteenth century, ${ }^{20}$ eventually declining somewhat in the fifteenth century and reaching a maximum in the sixteenth century. ${ }^{21} \mathrm{~A}$ frequent trade commodity that was shipped from Bremen to Bergen was beer. ${ }^{22}$ Beer from Bremen is occasionally mentioned as having been delivered to the royal fortress of Bergenhus, which indicates a certain appreciation of this beverage also in a high status, non-Hanseatic environment. ${ }^{23}$
Summing up, the late medieval and early modern pottery is a material manifestation of the influence of Hanseatic culture in Bergen as it is widely known from historiographical research.

\section{Table culture and consumption habits}

The fact that the vast majority of the Bergen pottery in the fourteenth and fifteenth centuries was drinking and pouring vessels points strongly to the conclusion that the pottery was mainly used for the consumption of beverages. It is well known from written sources that, in addition to rye and other grain, considerable amounts of beer - and to a certain extend wine - were imported by Hanseatic merchants to Bergen. ${ }^{24}$ Thus, it seems convincing to interpret the German stoneware jugs as the appropriate tableware for the consumption of the probably highly valued imported beverages. The larger jugs and beakers may have been used for beer, whereas smaller vessels may have been used to drink wine. Considering that all these beverages were traded, transported and stored in barrels, it is clear that the ceramic tableware was used to get wine and beer from the barrel and to serve and drink the beverages at the table. A similar theory was convincingly presented by the French archaeologists Deroeux and Dufournier in 1992, in relation to French pottery from the thirteenth and early fourteenth centuries found in Bergen. ${ }^{25}$ Saintong pottery from southwestern France was interpreted as markers of French wine imported to towns all along the North Sea. The characteristic Saintong tableware would have been a visible sign for the consumer that genuine wine from south-western France was served. Though this trade with wine is known from written sources, it does not directly appear in the archaeological material as both the product (wine) and the container (barrel) were consumed or have decayed. However, Saintong pottery appears regularly in harbour towns where the import of French wine is likely. If we transfer this model to the late medieval trade with German stoneware, we might see at least a part of the stoneware as a reflection of the import of northern German beer and wine from the Rhine region. However, due to the sheer amount of Rhenish stoneware, a significant part of this was probably traded for itself and not in connection with any other commodity. Nevertheless, it is striking that a considerable quantity of different drinking and pouring vessels was found in the ruins of the Bergen wine cellar. ${ }^{26}$ Among other finds, a large 


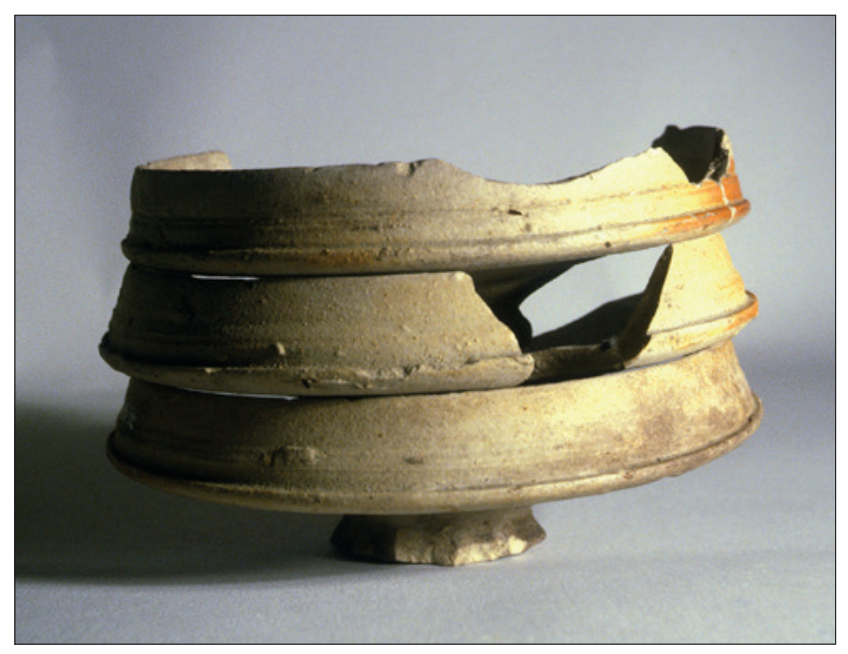

Fig. 3. Three Siegburg stoneware wine bowls, excavated in the ruins of the wine cellar in Bergen (photo: Volker Demuth).

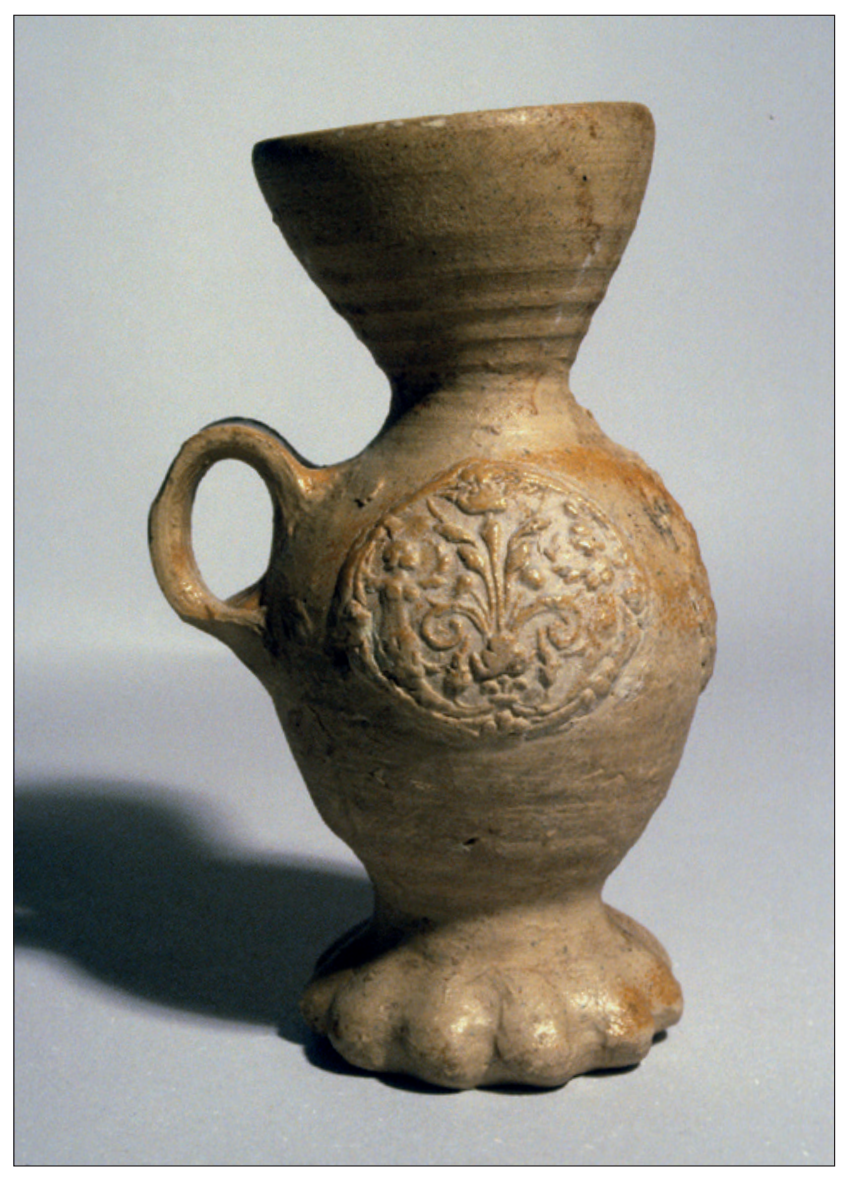

Fig. 4. Siegburg funnel beaker, found at Bryggen in Bergen (photo: Volker Demuth).

number of small Siegburg stoneware bowls was discovered and interpreted as specialised drinking vessels for wine (Fig. 3). Wine from the Rhine area was imported to Bergen in large quantities and it seems obvious that the small bowls would have been the appropriate tableware for Rhenish wine for the con- temporary drinker. It is notable that these bowls are found almost exclusively in the ruins of the Bergen wine cellar, the only officially legalized point for retail sale of wine. Aside from these quite special drinking bowls, also funnel-necked beakers, which were a common type of Siegburg stoneware in the fifteenth and sixteenth centuries, were most likely designed as drinking vessels for wine as can be deduced from their comparatively small volume (Fig. 4).

Larger stoneware jugs, however, were of multifunctional shape and may have regularly been used for the consumption of beer. The import of large quantities of northern German beer via the Hanseatic network to Norway, where it was quite popular, is documented by written sources. Especially regarding the quite distinct Lower Saxon stoneware it is likely that it was associated with the popular beer from that region. The Hanseatic hinterland along the Weser River was well known for the beer brewed in towns like Einbeck and Braunschweig, but the harbour cities of Bremen, Hamburg and others also had extensive breweries. ${ }^{27}$ According to tax rolls, northern German beer was quite commonly imported to Bergen. ${ }^{28}$ Following the model proposed by Deroeux et al., ${ }^{29}$ the brown or reddish Lower Saxon stoneware may have functioned as a marker for northern German beer, which had a long shelf-life and was highly valued for its high quality, due to the use of hops and its high alcohol percentage.

\section{Mentality and ideology mirrored in pottery decoration}

From the sixteenth century on, highly decorated pottery in the form of relief-decorated stoneware and painted earthenware became more prevalent, both in northern German production areas and in Bergen. Exceeding the purely ornamental aspects of this decoration, the pottery functioned also as medium for images that evoke meanings. Maybe the most common image on stoneware throughout the late medieval and early modern period is the Bartmann, depicting a bearded male face on the neck of the well-known Bartmann or Bellarmine jugs. In Bergen, the oldest examples of this motif appear on Saxon stoneware jugs from Waldenburg, dating to the late fourteenth and early fifteenth century. Curiously, the best-preserved piece is not a real Waldenburg jug, but a very rare copy made of glazed red earthenware (Fig. 5). This piece, with the only known parallels in Riga and Helsingborg, was probably produced somewhere in the southern Baltic. ${ }^{30}$ It shows the popularity of the bearded man im- 


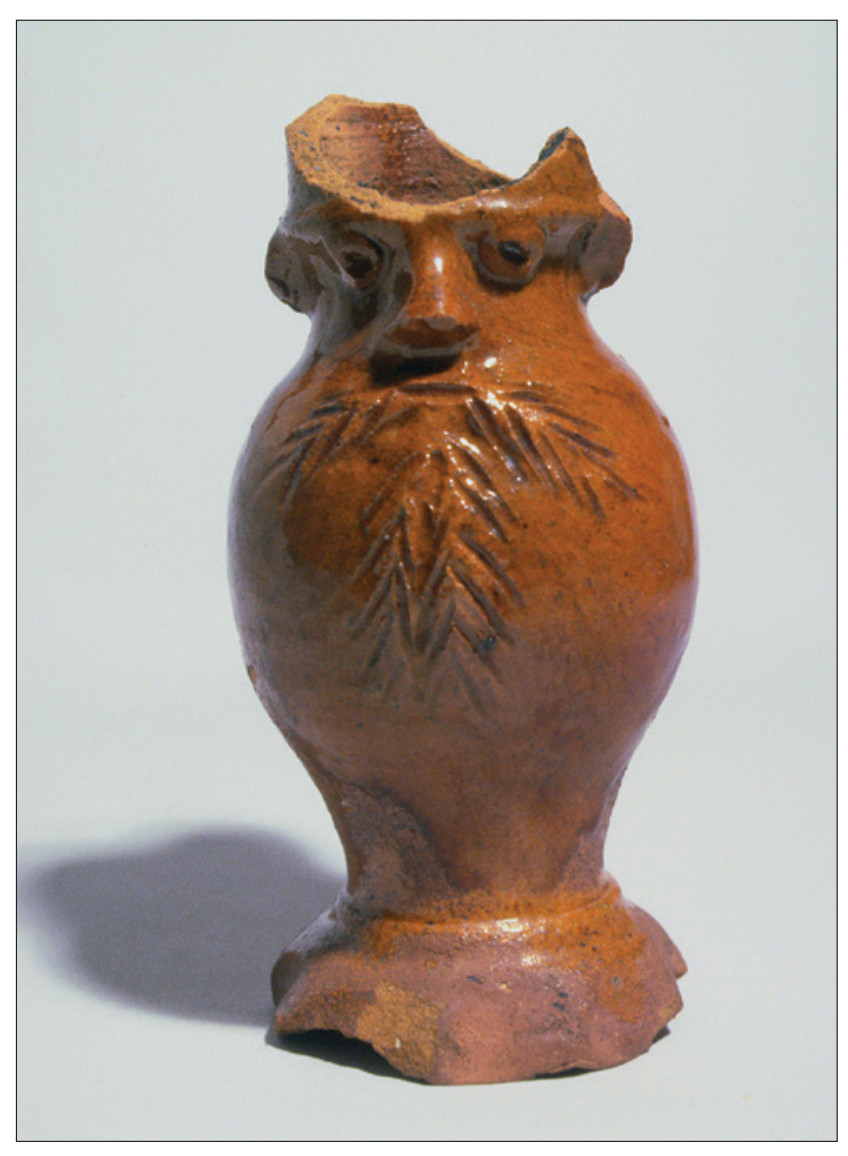

Fig. 5. Glazed redware copy of a Waldenburg stoneware jug with bearded facemask found in Bergen (photo: Volker Demuth).

age already in the fifteenth century. The iconography of the bearded man is most probably connected to the idea of the 'wild man' as a symbol of untamed manhood and male power. ${ }^{31}$ It is quite interesting to find this symbol regularly on vessels for the consumption of presumably alcoholic drinks, strongly indicating a connotation of drinking and masculinity, which seems to be a characteristic of early modern mentality. ${ }^{32}$ Bartmann jugs are found quite frequently in Bergen, both in the Bryggen area, but also at sites that were clearly inhabited by ethnic Danish-Norwegians, as a sixteenth century example from the royal castle in Bergen exemplifies. It seems likely that the adoption of these drinking vessels also indicates an adoption of the corresponding mind-set.

Other frequent motifs on early modern stoneware include various coats of arms, representing miscellaneous noble houses of contemporary Europe. Aside from a mere representation of the sovereignty over territories where the actual pottery was produced or consumed, these coats of arms may also represent important actors in the turbulent political landscape of Early Modern Europe. To give an example, it seems astonishing to find the royal Swedish Wasa coat of arms in the Danish-Norwegian town of Bergen. Yet, maybe the Trekronor (the three crowns) were in this case seen as a symbol of the major Protestant power in the struggle of the Thirty Years War and thus a political statement. Seen this way, also the coats of arms of Saxony or Jülich-Kleve-Berg would not only have represented the territorial rulers of important stoneware production areas, but also an important arena for the religious and political struggles of the period. The Electorate of Saxony was from the very beginning the most important stronghold of the Lutheran reformation. The United Duchies of Jülich-Kleve-Berg were not only an important regional actor in the Rhine area, housing many of the most important stoneware production centres, but with the War of the Jülich Succession, the object of a larger Protestant-Catholic conflict, which can be seen as an anticipation or prelude to the Thirty Years War. So, for the contemporary consumer, these coats of arms may have had an implicit political meaning in the light of the deep religious struggles that in many ways dominated the sixteenth and early seventeenth century. These conflicts are also clearly mirrored in the religious motifs that were common on highly decorated stoneware from the early modern period, which explicitly convey Protestant ideas and belief. ${ }^{33}$

\section{Medieval and early modern pottery found in non-urban harbour sites}

After this introduction of pottery in Norway, based on finds from Bergen, I want to direct some attention to finds of such pottery outside the urban centres. The most important non-urban find spots for late medieval and early modern ceramics in Norway are coastal sites, most probably connected to coastal trade. At several of these sites, medieval German stoneware was found on the seabed.

North of Trondheim on the small island of Nærøy, by a sound known as 'Market-sound' (Martnasundet), written sources document mercantile activities from the seventeenth to the nineteenth centuries. ${ }^{34}$ During underwater surveys, among numerous other finds, there was a find of an early fourteenth century jug of Lower Saxon stoneware, presumably from Bengerode. This intact jug is almost identical with a find from Bergen - where the pottery was most probably acquired. It is uncertain whether the jug was part of a cargo or part of personal belongings. If it was cargo, it may have been transported either by Norwegian 


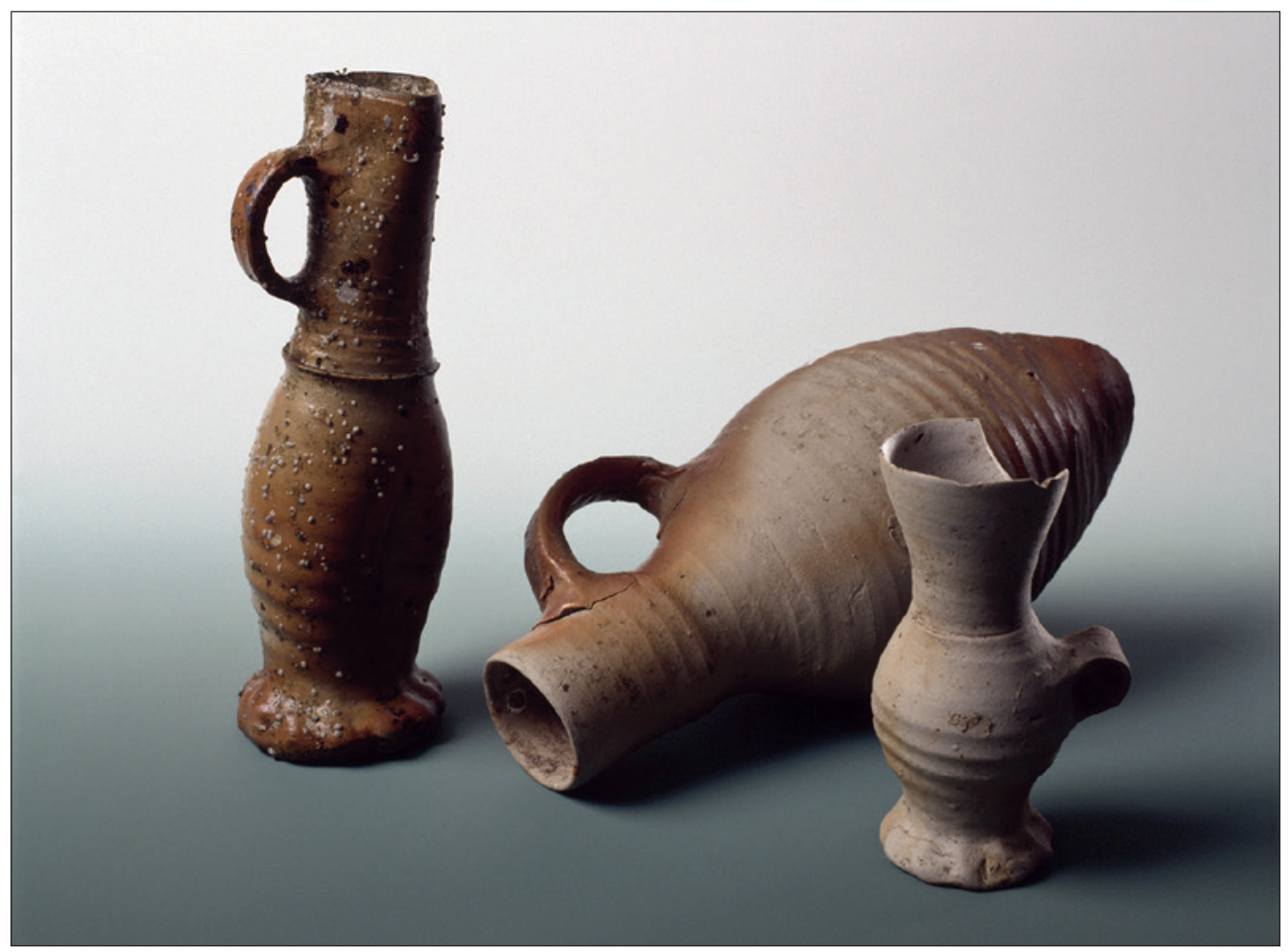

Fig. 6. Siegburg stoneware jugs found on the seabed of the medieval harbour in Avaldsnes (photo: Terje Tveit, Museum of Archaeology, University of Stavanger).

merchants, who had the privilege for the trade along the coast north of Bergen, or by Hanseatic merchants, illegally sailing northwards. The piece may, however, also have belonged to a north Norwegian fisherman, who traded directly with the Hanseatic merchants in Bergen. In any case, it is clear that this jug was distributed along the coast - also outside the urban centres. If the proposal that the Lower Saxon stoneware was a marker for imported beer is correct, this jug may be an indication that imported beer was also available on the northern market.

Another small, natural harbour, where presumably mercantile activities were carried out is the small bay Prestvika (Priest's Bay) on the southern cost of Norway, in the parish of Bamble in Telemark. A recent survey detected a significant number of Siegburg stoneware, indicating a coastal trading place. ${ }^{35}$ In this context, it is interesting to note that written sources from around 1600 explicitly mention that pottery was exported from Rostock with destination Langesund, ${ }^{36}$ which is a small trading town quite near to Prestvika. The combination of written and archaeological sources can, in this case, provide a more complete picture of the trading activities in this region. The archaeological evidence may indicate that the pottery which, according to the Sound toll, was to be shipped to Langesund may have been traded not in the town of Langesund, but in the small natural harbour nearby. To sum up, it is worth keeping in mind that pottery - at least in the
Early Modern period - was traded directly from the large Hanseatic harbour towns in the Baltic to minor places along the coast of southern Norway.

The most exciting non-urban harbour site along the Norwegian coast is Avaldsnes, on the island of Karmøy, approximately halfway between Stavanger and Bergen. ${ }^{37}$ The variety of pottery that has been picked up from the seabed at Avaldsnes paints a similar picture as the pottery found in Bergen. However, in contrast to Bergen, no English pottery has yet been found in Avaldsnes. The material is dominated by Siegburg stoneware (Fig. 6), but there are also redware cooking pots from the Netherlands and some Lower Saxon stoneware. Thus, the archaeological material makes it very likely that the harbour of Avaldsnes in the fourteenth and fifteenth centuries was frequently visited by merchants from the Hanseatic realm and that their material culture was available and maybe dominating in Avaldsnes. Together with the other sources - written sources as well as archaeological sources mentioned above - the pottery found in the harbour of Avaldsnes can be taken as evidence to support the thesis of a Hanseatic harbour at the site (see Ersland and Fyllingsnes, this volume). One other fascinating item that deserves mention is a fragment of a ceramic horn, a so-called Aachhorn or pilgrim's horn (Fig. 7). Similar fragments were also found in Bergen. These musical instruments were produced in large numbers in several pottery villages in the Rhine area, 


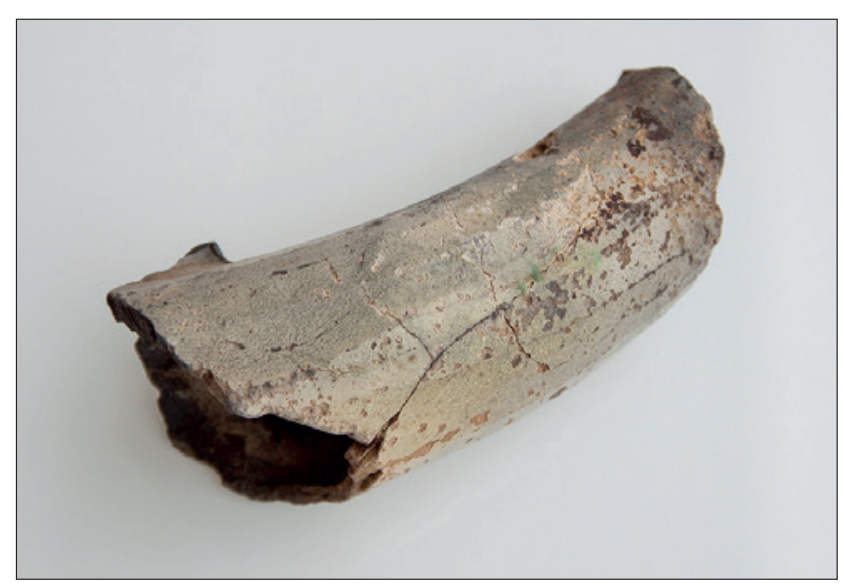

Fig. 7. Fragment of an 'Aachhorn' found underwater in Avaldsnes (photo: Cathrine Glette, Nordvegen History Centre, Avaldsnes).

such as Langerwehe, Brühl and others. ${ }^{38}$ There are a number of sources that indicate the use of similar ceramic horns in the rites of the pilgrimage to Aachen. ${ }^{39}$ Thus, the horns may be seen as a kind of pilgrim badge, indicating a pilgrimage to Aachen. Though especially in a maritime context such as Avaldsnes, the piece may possibly also be interpreted as signal horn, as it would have fulfilled this purpose quite well.

\section{Medieval and early modern pottery from rural settlements in northern Norway}

Aside from the medieval towns I have found during my research for this paper, there are very few find spots with late medieval and early modern pottery on land. Generally, it seems that a region with more frequent finds of medieval pottery in a rural context is northern Norway. ${ }^{40}$ Whether this reflects the state of research, better preservation condition or a historical reality remains uncertain. It probably mirrors both the extensive excavations on the 'Tell-like' farm mounds in the north, with well-preserved cultural layers and the historical reality of close economic bonds between the fishing population and Hanseatic traders. The dried cod from the fisheries of northern Norway was of great importance for the Hanseatic trading network. Taking the volume of trade into account, it seems at least plausible that this connection is represented by pottery finds in the north. During the thirteenth to fifteenth centuries, pottery seems to be mostly concentrated in the urbanised mercantile centre of Vågan or the administrative centre of Trondenes, close to Harstad. ${ }^{41}$ In early modern times, ceramics also became more frequent at rural sites. Still, it is obvious that there seems to be a concentration of Hanseatic pottery in farm mounds in the proximity of administrative centres, such as the parish of Trondenes. One example is a rim fragment of a fifteenth century Siegburg jug found during excavations at a farm site in Bergsodden, a few kilometres from Trondenes church..$^{42}$ It thus can be assumed that the pottery found in the farm mounds of the north reflects the fact that typical Hanseatic pottery, such as Siegburg jugs, was both available for and used by at least parts of the rural population of northern Norway. This can be explained by the structures of trade, where the producers of fish in the north sailed with the dried fish to Bergen to exchange it with Hanseatic merchants directly for grain and grain products. ${ }^{43}$ It can be assumed that this direct contact with Hanseatic traders and seafarers led to the adoption of typical Hanseatic material culture as manifested in the Siegburg stoneware.

\section{Pottery outside the urban centres in south-eastern Norway}

To my knowledge, there are no finds of fourteenth- or fifteenth-century pottery in a non-urban context in south-eastern Norway. While this may be due to the poor state of research, it is striking that pottery appears in contexts from the sixteenth century and later despite the small amount of archaeological research that has been done on early modern rural sites in Norway. There are, however, some finds of imported pottery from the sixteenth and seventeenth centuries found in various places around the Oslo fjord. At a place named Labo, situated on the coast approximately 40 kilometres southeast of Oslo, the regional cultural heritage institution, Akershus fylkeskommune, carried out research on a site that had been a local trading spot since the Middle Ages. Amongst the many finds, one particular piece stands out; it is a small fragment of a Siegburg tankard with the coat of arms of JülichKleve-Berg. This small piece resembles the many finds with similar ornamentation in the material found in Bergen. Obviously, this characteristic sixteenth- and early seventeenth-century Hanseatic pottery was to a certain extent available on the local market in minor trading spots, but we have little evidence to determine whether this material was only used by merchants that carried out business at these places or whether this pottery was also traded from the marketplace into the rural environment. 


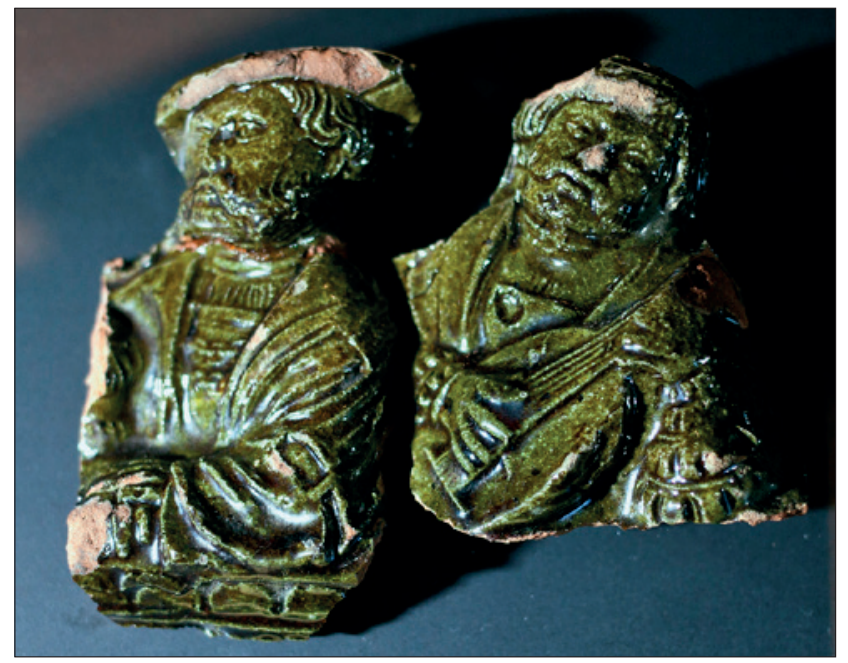

Fig. 8. Fragments of two green glazed stove tiles, found at a mid-sixteenth-century mining site near Seljord, Telemark (photo: Christian Berg, The Norwegian Mining Museum, Kongsberg).

In areas more distant from the coast, there seems to be even less late medieval or early modern pottery. However, I shall present some of the rare finds here. In the inland of Telemark, in Seljord parish, the Norwegian Museum of Science and Technology conducted research prior to the building of a dam on the site of a cobber ore mine that was in use in the 1540 s. ${ }^{44}$ During that excavation, fragments of a mid-sixteenth century stove tile were found. The pieces, one showing presumably the Saxon Elector Johann the Steadfast was produced in central Germany and is the earliest stove tile in inland Norway to my knowledge (Fig. 8). It was found in the remains of an ore-smelting plant from the $1540 \mathrm{~s}$. The stove from which the fragments derive belonged to a mining operation that was conducted by German miners, who were hired by Christian III. ${ }^{45}$ Possibly, this stove did not heat a dwelling, but rather an ore-processing workshop, as described in the sixteenth-century book about mining by Georg Agricola. ${ }^{46}$ As the finds are closely connected to the mine and the smeltery, the users of the imported ceramic inventory were in this case clearly immigrant German miners; according to written documents, they were the only ones involved in the mining and metallurgical process. Interestingly, the mining expedition was partly financed by merchants from Hamburg, who supervised the work and were partially present near the mine in the $1540 \mathrm{~s}$, showing the involvement of a major player in the Hanse League in this development process. ${ }^{47}$

The local farming population in inner Telemark, however, does not seem to have shown any inclination to adopt any cultural traces of these immigrants. On the contrary, they tried to revolt against the king and expel the miners. ${ }^{48}$

\section{Conclusion}

The paper tries to provide an overview of certain pottery finds, mostly stoneware, produced in northern Germany and exported to Norway during the late medieval and early modern period. Commonly found in urban northern European contexts dominated by mercantile activities of Hanseatic merchants, the presented artefacts are so closely related that these stoneware finds may be convincingly described as 'type fossils' for Hanseatic culture. ${ }^{49}$

A central aspect of this paper was to analyse the differences in the pottery sequences in urban and rural environments in Norway. There is obviously a difference in the use of pottery between urban and rural Norway in late medieval and early modern times. There is maybe an even stronger difference between rural coastal areas and inland Norway. This concerns both the use of pottery and the acceptance of associated cultural patterns. How may these be explained? It seems striking that Hanseatic pottery appears mainly where also persons with a Hanseatic background were present ${ }^{50}$ or where the interaction with Hanseatic merchants was crucial for economic survival/prosperity. I propose that the physical contact and the interaction with people from a different cultural background is the most important step in adopting cultural patterns. The reason for the comparatively larger amount of pottery in northern Norway farm mounds may be that, for the fisher-farmer population of northern Norway, the interaction with Hanseatic merchants was of mutual benefit and the trading resulted in an increased quality of life for the fisher-farmers. ${ }^{51}$ A representative selection of peasant fishermen participated in the fish transport to Bergen and thus were periodically present in the town, where they would have become acquainted with the urban lifestyle of the Hanseatic merchants. In this way, the rural population of coastal Norway seems to have adopted Hanseatic material culture according to the need and opportunity of interacting with foreign merchants. In the inland, on the other hand, there seems to have been few opportunities and incentives to interact with foreigners. This may be due to purely geographic reasons but perhaps also due to a more conservative mentality. In any case, the rural population of inland Norway obviously did not adopt the table habits of the Hanseatic world, although there had to be a certain contact with or knowledge of Han- 
seatic sea trade. The region discussed is situated by the Telemark waterway, along which various goods were transported. Products from inner Telemark, such as Eidsborg hones, were widely used in the Hanseatic world, as proven by, for example, the finds on the socalled Darss shipwreck. ${ }^{52}$ The medieval stone churches of Kviteseid and Seljord along the waterway have chalk paintings showing seafaring ships. ${ }^{53}$

The episode about the conflict with foreign miners may be interpreted as follows: when the inland farming population had the opportunity to meet foreigners, they would go to any length to get rid of anyone who might have represented a challenge to their traditional lifestyle rather than to adopt their ways. This may well have been the case, as contact with strangers would have held little benefit for the inland farmers. This was probably a striking difference to the situation along the northern Norwegian coast.

To sum up, I would interpret the spreading of medieval and early modern pottery as yet another indication of the importance of cities and sea trade for the transferring of cultural phenomena in this period.

\section{Endnotes}

${ }^{1}$ Reed 1994.

${ }^{2}$ Reed 2009.

${ }^{3}$ Gaimster 1997, $148 f$.

${ }^{4}$ Lüdtke 1989, 11.

${ }^{5}$ Blackmore and Vince 1994; Demuth 2001; Deroeux et al. 1994; Lütdke 1989; Tøssebro 2012.

${ }^{6}$ Lüdtke 1989, 28.

${ }^{7}$ Mehler 2009.

${ }^{8}$ Gaimster 1997, 144.

${ }^{9}$ Øye 1998 .

${ }^{10}$ Herteig 1989, 12.

${ }^{11}$ All these statistic data are extracts from my ongoing $\mathrm{PhD}$ project. The basis is the number of single fragments and the recorded find contexts, as documented in the main database for the structures and artefacts from the excavations at Bryggen.

${ }^{12}$ Schäfer 1996.

${ }^{13}$ Ibid., 322-329.

${ }^{14}$ König 2007, 126.

${ }^{15}$ There are a number of studies on production sites of Lower Saxon stoneware such as Coppengrave (Stephan 1981) or Bengerode (Grote 1976; Lönne 2004). A summing up volume on the material was published in connection with an exhibition in 2012 (Leiber 2012; Stephan 2012).

${ }^{16}$ Rech 2004, 223, 225.

${ }^{17}$ Heege 2002, 258.

${ }^{18}$ Schreiner 1963; Helle 1982.

${ }^{19}$ von Witzendorff 1955, 142.

${ }^{20}$ Nedkvitne 2014, 87.
${ }^{21}$ Ibid., 221.

${ }^{22}$ von Blanckenburg 2001, 22.

${ }^{23}$ Nedkvitne 2014, 225.

${ }^{24}$ Helle 1982.

${ }^{25}$ Deroeux et al. 1994.

${ }^{26}$ There were several excavation campaigns in the Bergen wine cellar. The architectural remains were published by Ekroll 1990 and an article based on a master thesis about pottery from the excavations was published online (Tøssebro 2012).

${ }^{27}$ Blanckenburg 2001.

${ }^{28}$ Helle 1982, 318.

${ }^{29}$ Deroeux et al. 1994.

${ }^{30}$ Russow 2004.

${ }^{31}$ Gaimster 1997, 280; Husband 1980.

${ }^{32}$ Roper 1994, 65, 67.

${ }^{33}$ Buckholm 1998; Gaimster 1997, 148.

${ }^{34}$ Nymoen 1994.

${ }^{35}$ Falck et al. 2013, 66.

${ }^{36}$ Möller 2008, 543.

${ }^{37}$ Elvestad and Opedal 2001.

${ }^{38}$ Klutig-Altmann 2015, 98.

${ }^{39}$ Haasis-Berner 1994.

${ }^{40}$ Brun 1996; Karoliussen 2008.

${ }^{41}$ Brun 1996, 56; Karoliussen 2008, 69.

${ }^{42}$ Pers. comment by the excavator, Morten Olsen.

${ }^{43}$ Nedkvitne 1988, 267.

44 Thuesen 1979.

${ }^{45}$ Berg 1999.

${ }^{46}$ Agricola 1556 [1928], 274f.

${ }^{47}$ Berg 1999, 41.

${ }^{48}$ Ibid. 38.

${ }^{49}$ Gaimster 2011, 344.

${ }^{50}$ For the discussion about Hanseatic material culture see e.g. Mehler 2009; Müller 2014.

${ }^{51}$ Nedkvitne 2014, 416.

${ }^{52}$ Förster 2002, 235.

${ }^{53}$ Dørum 2014, 69.

\section{References}

Agricola, G. 1556 [1928]. De re metallica libri XII, Basileae. Zwölf Bücher vom Berg- und Hüttenwesen. Berlin: VDI Verlag.

Berg, B. I. 1999. Die frühen norwegischen Bergwerke. Zuwanderung, Technologie und Kultur aus Deutschland, in J. Simensen (ed.), Deutschland Norwegen. Die lange Geschichte, 34-49. Otta: Tano Aschehoug.

Blackmore, L. and Vince, A. 1994. Medieval pottery from south-east England found in the Bryggen excavation 1955-68. The Bryggen Papers, Supplementary Series vol. 5, 9-160. Bergen: Scandinavan University Press.

von Blanckenburg, C. 2001. Die Hanse und ihr Bier. Brauwesen und Bierhandel im hansischen Verkehrsgebiet. Köln: Böhlau.

Brun, T. A. 1996. Middelalderkeramikk. Et perifert materiale i det sentrale Nord-Norge. Unpublished Master thesis, University of Tromsø. 
Buckholm, M. B. 1998. Lov og nåde. Et billedlig fremstilling av den gamle og den nye pakt på et krus fra Bryggen, in A. Ågotnes (ed.), Tingenes tale. Funn fra Bergen og fra Vestlandet 1000-1600, 96-99. Bergen: Bryggens museum.

Demuth, V. 2001. Weser and Werra Ware in Bergen. Archaeological Perspectives on the Town's Early Modern Period. Bryggen Papers, Supplementary Series vol. 7, 69-137. Bergen: Fagbokforlaget.

Deroeux, D., Dufournier, D. and Herteig, A. E. 1994. French medieval ceramics from the Bryggen excavations in Bergen Norway. The Bryggen Papers, Supplementary Series vol. 5, 161-208. Bergen: Scandinavian University Press.

Dørum, K. 2014. Fra istid til ca. 1100, in Ø. Rian (ed.), Telemarks historie, 21-90. Bergen: Fagbokforlaget.

Ekroll, Ø. 1990. Byens herlighed. Riksantikvarens skrifter Nr. 6. Oslo: Riksantikvaren.

Elvestad, E. and Opedal, A. (eds ) 2001. Maritimarkeologiske forundersøkelser av middelalderhavna på Avaldsnes, Karmøy. AmS-Rapport 18. Stavanger: Arkeologisk museum Stavanger.

Falck, T., Løseth, K., Nymoen, P., Nævdal, D. and Vangstad, H. 2013. Faglig program. Problemstillinger knyttet til arkeologiske havner. Norsk Maritimt Museum Arkeologisk rapport Nr. 2013:1. Oslo: Norsk Maritimt Museum.

Förster, T. 2002. Alltagsleben auf spätmittelalterlichen Schiffen - Neue archäologische Untersuchungen an Wrackfunden vor der Küste von MecklenburgVorpommern, in K. Krüger and C. O. Cederlund (eds), Maritime Archäologie heute, 232-236. Rostock: Ingo Koch Verlag.

Gaimster, D. 1997. German Stoneware. Archaeology and Cultural History. London: British Museum Press.

Gaimster, D. 2011. Archaeology of a trade network: the Hanseatic League, 1200-1500 AD, in M. Carver and J. Klápště (eds), The Archaeology of Medieval Europe, vol. 2, 340-349. Aarhus: Aarhus University Press.

Grote, K. 1976. Bengerode, ein spätmittelalterlicher Töpfereiort bei Fredelsloh im südlichen Niedersachsen. Nachrichten aus Niedersachsens Urgeschichte 45, 245-304.

Haasis-Berner, A. 1994. Hörner aus Keramik Wallfahrtsdevotionalien oder Signalhörner? Zeitschrift für Archäologie des Mittelalters 22, 15-38.

Heege, A. 2002. Einbeck im Mittelalter. Oldenburg: Isensee.

Helle, K. 1982. Bergen bys historie. Kongssete og kjøpstad. Fra opphavet til 1536, vol. 1. Bergen: Alma Mater forlag.

Herteig, A. 1989. The buildings at Bryggen. Their topographical and chronological development. The Bryggen Papers, Main Series, vol. 3. Oslo: Norwegian University Press.

Husband, T. 1980. The Wild Man. Medieval myth and symbolism. New York: Metropolitan Museum of Art.

Karoliussen, Y. N. 2008. Europeisk importkeramikk i nordnorsk kontekst. Keramikkens bruk og betydning innenfor det nordnorske samfunnet i perioden 1400-1800 e. Kr. Unpublished Master thesis, University of Tromsø.
Klutig-Altmann, R. 2015. Eine frühneuzeitliche Keramikfanfare aus Wittenberg im Kontext der Funde gewundener Hörner aus Deutschland, in H. Meller (ed.). Fokus Wittenberg: Die Stadt und ihr Lutherhaus. Multidisziplinäre Forschungen über und unter Tage, 93-132. Langenweißbach: Beier \& Beran.

König, A. 2007. Keramikfunde aus höxterschen Haushalten der ersten Hälfte des 15. Jahrhunderts, in F. Lichtwark (ed.), Keramik auf Sonderwegen. Denkmalpflege und Forschung in Westfalen 44, 121-130. Mainz: Philipp von Zabern.

Leiber, C. (ed.) 2012. Aus dem Pottland in die Welt. Eine historische Töpferregion zwischen Weser und Leine. Holzminden: Jörg Mitzkat.

Lönne, P. 2004. Die mittelalterliche Töpfereiwüstung Bengerode bei Fredelsloh, Ldkr. Northeim, in F. Both, H. Haßmann and M. Fansa (eds), Archäologie Land Niedersachsen. 25 Jahre Denkmalschutzgesetz. 400000 Jahre Geschichte, 264-265. Stuttgart: Theiss.

Lüdtke, H. 1989. The Bryggen Pottery I: Introduction and Pingsdorf Ware. The Bryggen Papers, Supplementary Series vol. 4. Bergen: Norwegian University Press.

Mehler, N. 2009. The perception and interpretation of hanseatic material culture in the North Atlantic: problems and suggestions. Journal of the North Atlantic, Special Volume 1, 89-108.

Müller, U. 2014. 'Archäologie' + 'Kultur' = 'Hansekultur'? Überlegungen zu einem Begriff, in A. Falk, U. Müller and M. Schneider (eds), Lübeck und der Hanseraum. Beiträge zu Archäologie und Kulturgeschichte. Festschrift für Manfred Gläser, 439-452. Lübeck: Schmidt-Römhild.

Möller, G. 2008. '...so sende ic to 1 tunne, dar es inne 13 dosin potte...' - Anmerkungen zum Keramikhandel im Ostseeraum des 13. bis 17. Jahrhunderts aufgrund der schriftlichen Quellen, in F. Biermann, U. Müller and T. Terberger (eds), 'Die Dinge beobachten...', 537-554. Rahden: Marie Leidorf.

Nedkvitne, A. 1988. 'Mens bønderne seilte og jagterne for'. Nordnorsk og vestnorsk kystøkonomi 1500-1730. Oslo: Universitetsforlaget.

Nedkvitne, A. 2014. The German Hansa and Bergen, 1100-1600. Quellen und Darstellungen zur hansischen Geschichte 60. Köln: Böhlau.

Nymoen, P. 1994. Handelsplasser på kysten. Maritimarkeologisk perspektiv på vareutveksling på senmiddelalderen. Unpublished Master thesis, University of Tromsø.

Rech, M. 2004. Gefundene Vergangenheit - Archäologie des Mittelalters in Bremen. Bremer Archäologische Blätter, Beiheft 3. Bremen: Landesarchäologie.

Reed, I. 1994. Late Medieval Ceramics in Norway. Medieval Ceramics 18, 59-65.

Reed, I. 2009. Trønderkeramikk - Adskillige Sorter Krustøi. Trondheim: Tapir akademisk forlag.

Roper, L. 1994. Oedipus and the Devil. Witchcraft, sexuality and religion in early modern Germany. London: Routledge.

Russow, E. 2004. Haruldane habemik Toompealt, in A. Haak, E. Russow and A. Tvauri (eds), Linnusest ja 
linnast. Uurimusi Vilma Trummali auks, 317-331. Tallinn: Teaduste Akadeemia Kirjastus.

Schäfer, H. 1996. Zur Keramik des 13. bis 15. Jahrhunderts in Mecklenburg-Vorpommern. Bodendenkmalpflege in Mecklenburg-Vorpommern, 297-335.

Schreiner, J. 1963. Bremerne i Bergen. Historisk Tidsskrift 42, 291-315.

Stephan, H.-G. 1981. Coppengrave. Studien zur Töpferei des 13. bis 19. Jahrhunderts in Nordwestdeutschland. Hildesheim: August Lax.

Stephan, H.-G. 2012. Das Pottland: Mittelalterliche und neuzeitliche Töpferei von landesgeschichtlicher Bedeutung und Keramik von europäischem Rang in Niedersachsen, in C. Leiber (ed.), Aus dem Pottland in die Welt. Eine historische Töpferregion zwischen Weser und Leine, 9-72. Holzminden: Jörg Mitzkat.
Thuesen, G. 1979. Den første dokumenterte bergverksdrift i Norge. Volund, 7-60.

Tøssebro, C. 2012. Wine and power. A spatial and stratigraphical study of the pottery and glass assemblages from the wine cellar in Bergen, Norway. Historische Archäologie 2012. Published online http:// www.histarch.uni-kiel.de/HistArch_2012_high.pdf [last access December 2017].

Øye. I. (ed.) 1998. Medieval fires in Bergen - revisited. The Bryggen Papers, Supplementary Series vol. 6. Bergen: Fagbokforlaget.

von Witzendorff, H. J. 1955. Bremens Handel im 16. und 17. Jahrhundert. Bremisches Jahrbuch 44, 128-174. 